\title{
THE PUBLIC HEALTH DIMENSIONS OF THE GLOBAL ECOLOGICAL INTEGRITY GROUP (GEIG) CONFERENCE, PRAGUE, CZECH REPUBLIC, JULY 9-16, 2011
}

\author{
Colin L. Soskolne \\ University of Alberta, Edmonton, Canada
}

The Global Ecological Integrity Group (GEIG) held its 19th annual conference at Charles University in Prague, Czech Republic, July 11-16, 2011. The conference was graciously hosted by Prof. Vladimír Bencko of the Charles University's First Faculty of Medicine in Prague, who, along with Professors Laura Westra and Colin Soskolne of Canada also co-organised the event. John Quinn provided invaluable support to all delegates throughout the conference.

Delegates numbered 55, from 15 countries. Kind sponsors included the First Faculty of Medicine of Charles University in Prague which provided magnificent conference facilities as well as refreshments throughout the 5-day event. The support provided by Sanofi-Pasteur in hosting our welcome reception in the historic Faust's House will go down as GEIG's best-ever such welcome event. And, not to forget all of the memorable experiences that come with being in one of the worlds great, historic, and intact cities that combine history with modernity; the boat and walking tours were highlights for the delegates, providing keen opportunities for immersion in over 1,000 years of history.

This 19th GEIG conference was particularly significant because the topic "Human Rights and Duties: Supporting Biological Integrity for Public Health" has been one of the major themes that GEIG has studied and discussed during the course of its 19-year history. However, this theme has been a main focus of our annual conferences only once before, in 1998, when a World Health Organization (WHO) Workshop at the European Centre for Environment and Health of the WHO in Rome, Italy, was co-organized by Colin Soskolne and Roberto Bertollini, the Centre's then Director. That Workshop included several of the founding members of GEIG.

The influence of GEIG, under the leadership of Laura Westra, extended unexpectedly far in that the 1998 WHO Workshop resulted in a 1999 WHO Discussion Document, which turned out to be the most accessed document on the WHO-EURO website for the succeeding three years. It is believed to have had a rather profound advocacy role, and it can be retrieved at the following link: http://www.colinsoskolne.com/documents/WHO-1999_Discussion_Document.pdf

Our latest thinking on these matters as reflected through the Prague conference will be published as the 20th anniversary collection of GEIG's collective work, sharing the focus on public health from the 1999 WHO Discussion Document. The book is expected to be published by Earthscan (an offprint of Taylor and
Francis, U.K.) for launch at the GEIG conference to take place June 18-23, 2012, La Rochelle, France.

The Prague conference keynote talk was provided by Sheila Abed, Chair of the Commission on Environmental Law of the International Union for the Conservation of Nature (IUCN). She traced possible conflicts and similarities between human rights law and the protection of indigenous peoples, with health being a major focus. The thread of Indigenous Peoples' rights was also stressed by Brad Morse and Valentina Vadi, describing some of the great lessons that may be learned from indigenous knowledge. Current difficulties present in human rights regimes were discussed by Kathleen Mahoney and Laura Westra, explicating mechanisms for focusing on the right to health. Several papers stressed the need for reform in global governance and legal regimes, especially those papers by Klaus Bosselmann, Ulrich Grober, Michael Schröter, Prue Taylor, Louis Kotzé, Sheila Collins, Geoff Garver, Megan Mitchell, and Kathryn Kintzele.

The implications for health and civilization of climate change were discussed by Donald Brown, Konrad Ott and Christian Baatz, Patricia Quillack, Ottavio Quirico and Antonio D'Aloia. Water issues were addressed by Joe Dellapenna, Owen McIntyre, Ruth Irwin and Anel du Plessis as foundational to civilization, health and well-being. Public health and ecological integrity were the focus of papers presented by Paul Carrick, Alex Lautensach, Colin Soskolne, Joseph Sejek, Jack Manno, William Onziwu, Don Spady, John Quinn, Vladimir Bencko, and Thomas Zeleny. The paper by Brunetto Chiarelli provided controversy in its emphasis on using technology to cope with increasing ecological stresses.

Several other papers provided a novel focus for our group. These included traditional medicine (Christina Rautenbach); alternative notions for the definition of health (Jan Payne), women's health issues (Yulia Lyamzina); migrant health problems (Helena Hnilicova); biodiversity (Carijn Beumer); agricultural issues (Franz-Theo Gottwald), vaccination in the control of infectious diseases (Rastislav Mad'ar), and fisheries (Mimi Lam). These were discussed in relation to their direct and indirect public health dimensions.

The broad range of presentations and the inter-disciplinary nature of this event represented the best of GEIG conferences. The challenge now remains to compile a volume for Earthscan publishers (Taylor and Francis, UK) that will do GEIG proud, serving the world in helping to guide us to a sustainable future, for both present and future generations. 